\title{
Attitude of dental interns, final year and third-year students towards their involvement in hospital work during COVID-19 pandemic in private dental colleges in Vidarbha, India
}

\section{VANDANA KOKANE}

V.S.P.M dental college, Nagpur.

NOOPUR KOKANE ( $\square$ nkokanegupta@gmail.com )

Dr.Rajesh Ramdasji Kambe dental college and Hospital, Akola.

Nitisha Saraf

V.S.P.M dental college, Nagpur.

\section{Sayali Ukey}

V.S.P.M dental college, Nagpur.

Shaishavi Satfale

V.S.P.M dental college, Nagpur.

\section{Research Article}

Keywords: covid-19, dental education, dental student, intern

Posted Date: March 2nd, 2021

DOI: https://doi.org/10.21203/rs.3.rs-287532/v1

License: (c) (i) This work is licensed under a Creative Commons Attribution 4.0 International License.

Read Full License 


\section{Abstract}

Background: because of the ongoing pandemic, dental education is severely affected. Even though as in every other field teachers have taken to virtual education, but in dentistry, no virtual lectures can even come close to the experience gained by students while practicing on patients. This study aims to evaluate student's attitudes regarding their involvement in hospital work at the time of the ongoing COVID19 pandemic and how it might impact their confidence and preparedness in the future.

Method: A validated questionnaire was circulated online among the students of five dental colleges of Vidarbha who have suspended all student activities on the campus of their college including internship. A total of 711 students responded.

Result: out of 711 students $52.9 \%$ of students are highly motivated to work in the hospital. However $52.7 \%$ are afraid of getting infected by the COVID-19 virus while working in the hospital, and $78.6 \%$ are worried that their loved ones can get infected because of them. $62 \%$ of students feel that they are less prepared for next year as they have no learned substantially in the last 6 months.

Conclusion: as the majority of students are highly motivated to work, private colleges should resume internships. This will benefit students as well as patients. Colleges should also consider calling in final year students in reduced batches, and allow them to assist or observe clinicians maintaining all precautionary protocols.

\section{Introduction}

Around six months back When COVID-19 was first detected in Wuhan, China it was a mysterious disease with lots of unknown parameters. Because of its unfamiliar nature, it created havoc all around the globe ${ }^{1}$. Rapid lockdowns were implemented, educational institutes were closed, work from home initiated ${ }^{2}$. The covid-19 disease has affected all aspects of life, personal, professional, and emotional ${ }^{1}$. The Healthcare industry was worse affected, where professionals have to work in constant fear of getting themselves infected.

Dentistry is one such sector that is severely affected by the unfamiliarity with the COVID-19 virus. For decades dentists have been protecting themselves and their patients from various blood-borne, bacterial, airborne infections, by following various guidelines issued by associations and administrations from time to time. But due to the mysterious nature of COVID-19 dentists have been advised to reduce their patients to only emergencies or completely closed their clinic for fear of spreading COVID-19 infection ${ }^{3}$. Dental education is severely affected, lectures have been shifted to virtual classrooms, clinics are suspended and the students are barred from being direct dental care providers ${ }^{4}$, which is a key component of the dental curriculum.

Government College has not suspended internships but private dental colleges have. The major concern is that with an absence of direct student patient contact, will students be confident enough to step up on 
the professional front. There have been various publications on the effect of COVID-19 on dental education but not many cover student's or interns' perspective about COVID-19 and their involvement in hospitals during the pandemic.

Hence this study is directed towards the dental interns, final year and pre-final year students in five private dental colleges in the Vidarbha region.

\section{Methods}

A cross-sectional study was undertaken among interns, final year and pre-final year students from 5 private dental colleges in Vidarbha, Maharashtra, India. These colleges have suspended clinics for students as well as interns. The survey was conducted via Google forms. The questionnaire and a small message explaining the aims and objectives of the study were sent to participants. The participants were approached by the principal investigator and co-investigator. The link of the form was sent to students on social networking groups and personal email addresses of students, Timely reminders were sent as well.

The participation was voluntary and all had an option of opting out of the study by not filling the questionnaire.

The study was conducted from August 14 to August 30, 2020. 711 students responded.

The pre-designed and structured questionnaire was based on the possibility of involvement of the dental interns, final year students in hospital work at the time of COVID-19. The questionnaire consists of 10 questions and their designations. The questions focused attitude of students and interns towards their involvement in hospital work during pandemics. The first question was to know how motivated students are for working in hospitals. The next question focused on their expectation about the hospital work. The next three questions focused on their preparedness for working in hospitals. Next three-question students were asked if they were afraid to work during pandemic. The next two questions focused on the student's parent willingness and the student's response to it.

\section{Result}

Figure 1 shows the distribution of students on basis of their designation $47 \%$ of respondents are interns, $29 \%$ are final year student and $24 \%$ are pre final year or third year students.

Majority of students are highly motivated to work in hospital during pandemic $52.9 \%$ and just around seven percent are not interested to work (Table 1 ). Around $54 \%$ respondents are expecting to do clinic work that is working on patients. Some $17.2 \%$ feel that they will not be doing any clinical work just spreading awareness, 119 respondents feel that they would be assisting clinician and 87 feel that they would be called back on COVID-19 duty of screening patients(Table 1). Only $32.3 \%$ think that they have acquired enough skills to work in hospital (Table 1 ) out of which $42.3 \%$ are interns (Table 2). About $50 \%$ will be confident to come back to hospital for working before the number of positive patients reduces (Table 1 ) out of which $59.8 \%$ are interns (Table 2 ). The reason why they are not confident may be 
because of COVID - 19 fears. $52.7 \%$ are afraid of contracting the disease while working in hospital (Table 3). $78.6 \%$ are afraid of infecting your loved one while working in hospital (Table3). $81.0 \%$ are afraid that they may have to work without PPE kits as there may be shortage of kits (Table 3).

Respondents were also asked about their parent's willingness, are they willing to send their children to hospitals for working during COVID-19 times.

$41.5 \%$ agreed that their parents are will to send their children to hospital for working.

We also asked them what they will do if their parents won't agree $53.2 \%$ said they will follow their parents' instruction and rest will follow their conscious.

Majority students $62 \%$ feel less prepared for the next year because of the lockdown (Table 1 ). Out of which $63.4 \%$ are interns (Table 2 ) 
Table 1

Response Analysis of the opinion of students to work in the hospital during the time of COVID-19

Pandemic

Questions

Highly motivated

Neutral

Uninterested

$49(6.9 \% 0$

What type of work you are expecting to do in hospital

Assisting clinicians

$119(16.7 \%)$

Screening and diagnosis (for COVID-19 patients)

$87(12.2 \%)$

Spreading awareness

$122(17.2 \%)$

Working on patients $383(53.9 \%)$

Do you think you have acquired necessary skill to work in hospital

Maybe $316(44.4 \%)$

No $165(23.2 \%)$

Yes $230(32.3 \%)$

If asked to assist in hospital earlier than expected (before corona patients count decreases)would you be confident

Maybe

249(35\%)

No

$110(15.5 \%)$

Yes

$352(49.5 \%)$

Do you feel less prepared for the next year because of the lockdown?

Maybe $168(23.6 \%)$

No 102(14.3\%)

Yes

$441(62.0 \%)$ 
Table 2

Students response based on their designations

\begin{tabular}{|c|c|c|c|c|c|c|c|c|c|}
\hline \multirow[t]{2}{*}{ designation } & \multicolumn{3}{|c|}{$\begin{array}{l}\text { Do you think you have } \\
\text { acquired necessary skill } \\
\text { to work in hospital }\end{array}$} & \multicolumn{3}{|c|}{$\begin{array}{l}\text { If asked to assist in } \\
\text { hospital earlier than } \\
\text { expected would you be } \\
\text { confident }\end{array}$} & \multicolumn{3}{|c|}{$\begin{array}{l}\text { Do you feel less prepared } \\
\text { for the next year due to } \\
\text { changes brought by }\end{array}$} \\
\hline & yes & No & $\begin{array}{l}\text { May } \\
\text { be }\end{array}$ & yes & No & May be & yes & No & $\begin{array}{l}\text { May } \\
\text { be }\end{array}$ \\
\hline $\begin{array}{l}\text { Third year } \\
\text { student }\end{array}$ & $17.5 \%$ & $39.2 \%$ & $43.3 \%$ & $36.3 \%$ & $26.3 \%$ & $37.4 \%$ & $63.2 \%$ & $10.5 \%$ & $26.3 \%$ \\
\hline $\begin{array}{l}\text { Final year } \\
\text { student }\end{array}$ & $28.4 \%$ & $21.6 \%$ & $50.0 \%$ & $43.6 \%$ & $15.2 \%$ & $41.2 \%$ & $58.8 \%$ & $17.2 \%$ & $24.0 \%$ \\
\hline intern & $42.3 \%$ & $16.1 \%$ & $41.7 \%$ & $59.8 \%$ & $10.1 \%$ & $30.1 \%$ & $63.4 \%$ & $14.6 \%$ & $22.0 \%$ \\
\hline$p$-value & 0.001 & & & 0.001 & & & 0.373 & & \\
\hline
\end{tabular}

Table 3

Fears of medical students to work in hospitals during COVID-19 Pandemic

\begin{tabular}{|ll|}
\hline Questions & Frequency \\
\hline Are you afraid of contracting the disease while working in hospital & \\
\hline Maybe & $211(29.7 \%)$ \\
\hline No & $125(17.6 \%)$ \\
\hline Are you afraid of infecting your loved one while working in hospital & $375(52.7 \%)$ \\
\hline Maybe & $96(13.5 \%)$ \\
\hline No & $56(7.9 \%)$ \\
\hline Yes & $559(78.6 \%)$ \\
\hline Are you afraid of working without PPE kits if there is shortage of kits & \\
\hline Maybe & $83(11.7 \%)$ \\
\hline No & $52(7.3 \%)$ \\
\hline Yes & $576(81.0 \%)$ \\
\hline
\end{tabular}

\section{Discussion}

Dental education is mainly composed of three parts: The first one is academic learning that is Lectures. The second part is Simulation laboratory courses and the third part is Clinical skill training ${ }^{5}$. The virtual classes on digital platforms have taken care of the first part. Preclinical and clinical training is most 
important for students, as they learn various manual and cognitive skills that prepare the students to enter the dental profession ${ }^{6}$. Due to the COVID-19 situation, the confidence and motivation of future dentists are jeopardized.

This study reveals that $52.9 \%$ of dental students are highly motivated to work as health care professionals. Another study reported motivation by medical students to be $62.2 \%$ during the COVID-19 pandemic ${ }^{7}$. Other findings indicate that the morale of the health professional workers was low in the beginning but was gradually built receiving motivational and psychological support from the general public and officials ${ }^{8}$.

In our study $53.9 \%$ of students expected to work on patients in hospitals in the pandemic. Also, $16.7 \%$ of students expected to assist clinicians in hospitals at the time of the pandemic. Similar to studies showed $36.1 \%$ of students agree on assisting clinicians ${ }^{9}$.

The students felt that the basic skills to work in the hospital were acquired by only $32.3 \%$ the findings are similar to previous studies carried on medical students ${ }^{7} .42 .3 \%$ of interns feel that they have acquired the required skills to be working in hospitals, only $17.5 \%$ of the third-year students feel that they have acquired skills to be working in the hospital. The reason behind this may be because interns have completed their posting in all departments in final and third year but third years did not complete posting in all departments due to lockdown

When asked about working confidently in a hospital $49.5 \%$ of students were confident to assist during a pandemic, which was not similar to the previous study ${ }^{5}$ where only $8.7 \%$ of students strongly agreed to work confidently. Interns were more confident but only $36.3 \%$ of third-year students were confident. The difference between them may be due to patient exposure they had in their clinical postings.

There was also fear among the students of getting infected (52.7\%) which is less as compared to results from Turkey where $82.3 \%$ of dental students are afraid of getting infected with the coronavirus. This difference may be due to of the overall present pandemic conditions in both countries. However students from both countries are equally worried to getting their loved one infected because of them as they are working in hospitals ${ }^{10}$.

Researches have shown that the lack of PPE has affected the morale of healthcare workers and other frontline warriors in fighting the coronavirus disease ${ }^{11}$. To conserve PPE for those on the frontlines fighting the coronavirus and to keep patients home, the ADA recommended on March 16, 2020, that dental offices should restrict their practice to only emergency cases ${ }^{12}$. Even in our study majority of students are afraid to work without PPE kits even though India has managed the condition very well and there is no shortage of PPE kits in India ${ }^{11}$.

Studies have shown that students seek career advice and approval from their parents ${ }^{13}$. This is more so true in the Indian scenario. Parents share equal fear of COVID-19 for their children. 
Hence in our study, we asked students about their parents $41.5 \%$ agreed that their parents are will to send their children to the hospital for work.

And when asked for others what if their parents did not permit them to work a hospital, $53.2 \%$ will go by their parents' will.

The whole dental fraternity is worried about the future of dentistry and dental students. Because due to the pandemic clinics have been suspended. Third-year and final-year students are not exposed to dental clinics and patients. Interns are not able to attend their clinical rotatory postings. And because of this $62 \%$ of respondents feel that they are less prepared for next year.

\section{Conclusion}

Even though the majority of students are afraid of infecting themselves and their loved ones are highly motivated to work in hospitals. However, they do feel that due to lockdown they have not acquired enough skill to work in the hospital, which makes them feel less confident and less prepared for next year. As students are motivated to work in hospitals, at least interns should be called back to work. This will be beneficial for interns as well as dental patients. As healthcare professionals they have a duty towards patients let them fulfill it. Final year students should also be called in batched and allowed to observe clinicians if not directly do patients. A virtual lecture can never compete with what is learned practically.

\section{Declarations}

1. Ethical approval : The study was approved by ethical committee of VSPM DCRC.

2. Participants consent: As the study was questionnaire study it was implicated that filling the form is the consent given by patients. There was a short message attached with questionnaires that agree to fill the form is giving consent.

3. Competing interests: the authors declare no competing interests.

\section{References}

1. Kokane N, Kokane V, Bengal S, "Attributes and Perception of People Who Delay Their Dental Treatment", IJDSIR- December - 2020, Vol. - 3, Issue - 6, P. No. 238-246.

2. Ravi RC. Lockdown of colleges and universities due to COVID-19: Any impact on the educational system in India?. J Educ Health Promot. 2020;9:209. Published 2020 Aug 31. doi:10.4103/jehp.jehp_327_20

3. Coulthard, P. Dentistry and coronavirus (COVID-19) - moral decision-making. Br Dent J 228, 503-505 (2020). https://doi.org/10.1038/s41415-020-1482-1

4. Ramamarayana V, Karuveettil V, Janakiram C. Dental public health: fallout of the COVID-19 pandemic.J Indian Assoc Public Health Dent2020;18:277-8 
5. Chang, T. Y., Hong, G., Paganelli, C., Phantumvanit, P., Chang, W. J., Shieh, Y. S., \& Hsu, M. L. (2020). Innovation of dental education during COVID-19 pandemic. Journal of Dental Sciences, 155. https://doi.org/10.1016/j.jds.2020.07.011

6. Alzahrani SB, Alrusayes AA, Aldossary MS. Impact of COVID-19 pandemic on dental education, research, and students. Int J Health Sci Res. 2020; 10(6):207-212.)

7. Rawat $P$, Joshi $C$, Joshi AK, et al. Involvement of Final year Medical Students in Hospital work during COVID-19 pandemic: A students' perspective. Research Square; 2020. DOI: 10.21203/rs.3.rs32214/v1.

8. Ismail AIAbri1, Rusinah bte Siron Health Care Professional Attitude and Motivation During COVID-19: A Case of Health Sector of Oman Systematic Reviews in Pharmacy Vol 11, Issue 9, Sept-Oct 2020

9. Choi, B., Jegatheeswaran, L., Minocha, A. et al. The impact of the COVID-19 pandemic on final year medical students in the United Kingdom: a national survey. BMC Med Educ 20, 206 (2020). https://doi.org/10.1186/s12909-020-02117-1

10. Ataş $\mathrm{O}$, Talo Yildirim T. Evaluation of knowledge, attitudes, and clinical education of dental students about COVID-19 pandemic. PeerJ 2020; 8e9575)

11. Sharma, N., Hasan, Z., Velayudhan, A., M. A., E., Mangal, D. K., \& Gupta, S. D. (2020). Personal Protective Equipment: Challenges and Strategies to Combat COVID-19 in India: A Narrative Review. Journal of Health Management, 22(2), 157-168. https://doi.org/10.1177/0972063420935540

12. CDC. Interim infection prevention and control guidance for dental settings during the COVID-19 response. CDC 2020. Available at: https://www.cdc.gov/coronavirus/2019-ncov/hcp/dentalsettings.html. Accessed September 22, 2020.

13. Taylor, J.D., Harris, M.B., \& Taylor, S.R. (2004). Parents have their say... About their collegeage children's career decisions. Journal of National Association of Colleges and Employers, 15-20

\section{Figures}

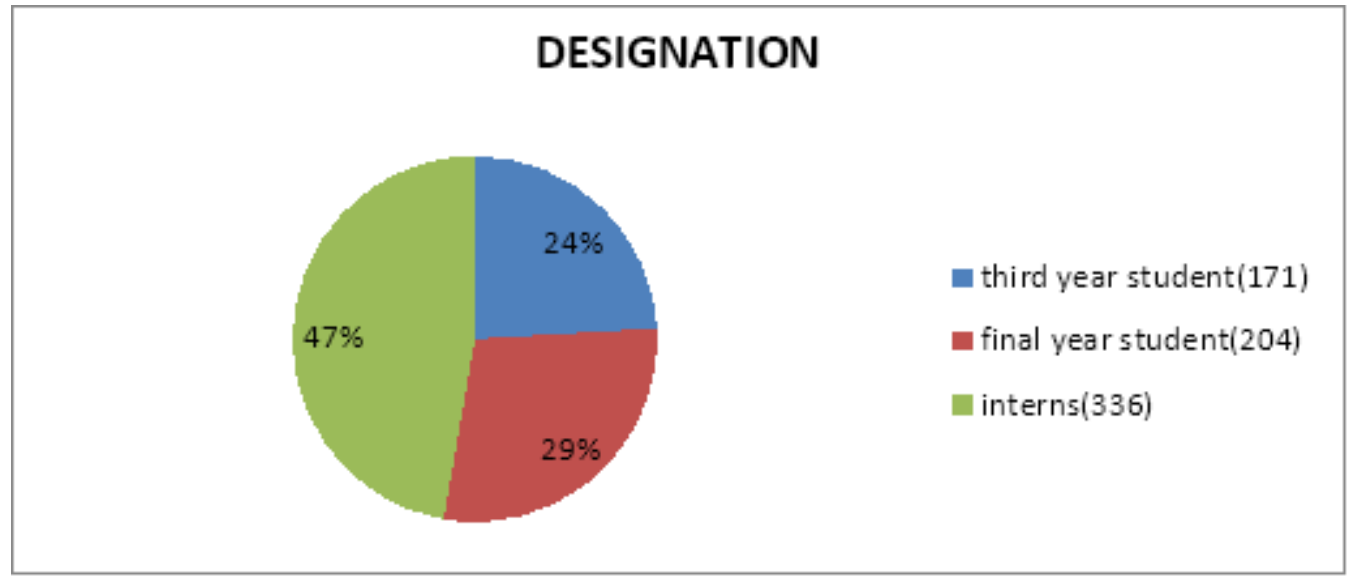

\section{Figure 1}


Designation of respondents.

Page 10/10 